\title{
Urinary tract infections in patients of University Hospital Center of Tirana
}

\author{
G Kasmi $^{1 *}$, S Bino ${ }^{2}$, I Kasmi ${ }^{3}$, S Tafai ${ }^{4}$, A Simaku ${ }^{2}$ \\ From International Conference on Prevention \& Infection Control (ICPIC 2011) \\ Geneva, Switzerland. 29 June - 2 July 2011
}

\section{Introduction / objectives}

Urinary tract infections (UTIs) are the most common type of nosocomial infections. The majority of nosocomial UTIs occur following instrumentation. Because nearly $10 \%$ of all hospitalized patients are catheterized, preventing nosocomial UTIs is a major factor in decreasing nosocomial infections. The aim of the study was to register the prevalence, etiology and antimicrobial susceptibility of nosocomial urinary tract infection pathogens isolated in UHC.

\section{Methods}

It was a cross-sectional study. In one day, a total of 893 urine samples were taken from hospitalized patients of UHC. The Vitek 2 automated system was used to identify and to detect antibiotic susceptibility. We collected data regarding etiology and antimicrobial resistance profile of the urinary isolates collected.

\section{Results}

The six most commonly isolated organisms were in decreasing order: E.coli, Candida sp, P.aeruginosa, E. cloacae, Klebsiella sp and Enterococcus sp.

The overall resistance rate to ampicillin in Gram negatives was $88 \%$.

The antimicrobial resistance patterns of the study isolates confirm the changes reported in nosocomial pathogens from other sources.

\section{Conclusion}

The prevalence rate of nosocomial UTIs was $18.9 \%$. These data show the high level of antimicrobial resistance amongst the uropathogens causing nosocomial UTIs. UTIs is related to the use of indwelling urinary catheters and other intravesical procedures. The levels

${ }^{1}$ Laboratory of Microbiology, Faculty of Medicine, Tirana, Albania

Full list of author information is available at the end of the article of resistance of pathogens must be a clear reason for stricter guidelines and regulations in antimicrobial policy.

\section{Disclosure of interest \\ None declared.}

\section{Author details}

${ }^{1}$ Laboratory of Microbiology, Faculty of Medicine, Tirana, Albania. ${ }^{2}$ Infectious diseases, Institute of Public Health, Tirana, Albania. ${ }^{3}$ Pediatric, University Hospital Center, Tirana, Albania. ${ }^{4}$ Laboratory of Microbiology, Hospital

"Shefqet Ndroqi", Tirana, Albania.

Published: 29 June 2011

\section{doi:10.1186/1753-6561-5-S6-P202}

Cite this article as: Kasmi et al:: Urinary tract infections in patients of University Hospital Center of Tirana. BMC Proceedings 2011 5(Suppl 6): P202.
Submit your next manuscript to BioMed Central and take full advantage of:

- Convenient online submission

- Thorough peer review

- No space constraints or color figure charges

- Immediate publication on acceptance

- Inclusion in PubMed, CAS, Scopus and Google Scholar

- Research which is freely available for redistribution
C Biomed Central
C Biomed Central

(0) 2011 Kasmi et al; licensee BioMed Central Ltd. This is an open access article distributed under the terms of the Creative Commons Attribution License (http://creativecommons.org/licenses/by/2.0), which permits unrestricted use, distribution, and reproduction in any medium, provided the original work is properly cited. 